(2) Open Access Full Text Article

LETTER

\title{
A paradigm shift in eye banking: how new models are challenging the status quo by Moshirfar et al
}

This article was published in the following Dove Press journal:

Clinical Ophthalmology

\section{Mark J Mannis}

Department of Ophthalmology \& Vision Science, University of California Davis Eye Center, Sacramento, CA, USA
Correspondence: Mark J Mannis

Department of Ophthalmology \& Vision Science, University of California Davis Eye Center, 4860 Y Street, Suite 2400,

Sacramento, CA, 95817, USA

Email mjmannis@ucdavis.edu

\section{Dear editor}

I read, with interest, the article by Moshirfar et $\mathrm{al}^{1}$ examining the shift in eye banking models that is occurring in our country. While the authors maintain that their purpose is to provide a fact-based, non-biased exposition of the current issues, they fall regrettably short of this goal. Of the 11 paragraphs in this paper, 6 are dedicated to outlining the advantages and contributions of the SightLife/ CorneaGen, while the criticisms of this new paradigm are skimmed over with mere lip service to the critics. If the authors had truly desired to provide a balanced picture, they would have written a paper that more fully outlines the objections to and concerns over the mixing of non-profit and for-profit organizations. $^{2}$

There is no mention of the World Health Organization Principles of Transplantation or the Barcelona Principles for Eye Banking, which have been endorsed by every major eye bank organization in the world including the EBAA, neither of which support a "for profit" model.

In eye banking, change is both inevitable and critical. There is no doubt that the industry has the wherewithal to facilitate true progress. However, we need to be clear about the role of for-profit institutions and their role in providing the gift of sight. Moshirfar et al do not provide us with a balanced picture, a most unfortunate analysis, clearly not free of bias.

\section{Disclosure}

The author reports no conflicts of interest in this communication.

\section{References}

1. Moshirfar M, Goldberg JL, Brown TW, et al. A paradigm shift in eye banking: how new models are challenging the status quo. Clin Ophthalmol. 2018;13:63-67. doi:10.2147/OPTH.S181534

2. Mannis MJ, Sugar J. Is this the future of eye banking? Cornea. 2018;37(7):811-812. doi:10.1097/ ICO.0000000000001616 
Dove Medical Press encourages responsible, free and frank academic debate. The content of the Clinical Ophthalmology 'letters to the editor' section does not necessarily represent the views of Dove Medical Press, its officers, agents, employees, related entities or the Clinical Ophthalmology editors. While all reasonable steps have been taken to confirm the content of each letter, Dove Medical Press accepts no liability in respect of the content of any letter, nor is it responsible for the content and accuracy of any letter to the editor.

\section{Publish your work in this journal}

Clinical Ophthalmology is an international, peer-reviewed journal covering all subspecialties within ophthalmology. Key topics include: Optometry; Visual science; Pharmacology and drug therapy in eye diseases; Basic Sciences; Primary and Secondary eye care; Patient Safety and Quality of Care Improvements. This journal is indexed on PubMed
Central and CAS, and is the official journal of The Society of Clinical Ophthalmology (SCO). The manuscript management system is completely online and includes a very quick and fair peer-review system, which is all easy to use. Visit http://www.dovepress.com/ testimonials.php to read real quotes from published authors. 